\title{
SERUM COMPLEMENT, RHEUMATOID FACTOR, AND OTHER SERUM PROTEINS IN RHEUMATOID DISEASE AND SYSTEMIC LUPUS ERYTHEMATOSUS
}

\author{
BY \\ H. A. ELLIS AND D. FELIX-DAVIES \\ Department of Experimental Pathology, University of Birmingham, \\ and the Queen Elizabeth Hospital, Birmingham
}

Several authors have reported serum complement changes in rheumatoid arthritis (Rachmilewitz and Silberstein, 1937; Vaughan, Bayles, and Favour, 1951a; Kellett, 1954), and have variously found low, normal, or high levels in different cases. More recently, Williams and Law (1958) have investigated serum complement changes in a variety of "connective tissue disorders", and have found that, in a group of 48 patients suffering from rheumatoid arthritis, the complement values were always high or within the normal range.

There are several possibilities which might explain these different findings. First, a variety of different diseases may be responsible for the clinical picture of "rheumatoid arthritis" and each of these may be associated with a different concentration of serum complement. One such example is systemic lupus erythematosus, where "rheumatoid arthritis" may be the prominent clinical manifestation and may lead to a mistaken diagnosis. It is known that serum complement levels may be low in systemic lupus erythematosus when estimated by haemolytic methods (Vaughan, Bayles, and Favour, 1951b; Elliott and Mathieson, 1953; Ellis and Walton, 1958; Williams and Law, 1958), and this might explain the low levels encountered in certain cases of "rheumatoid arthritis".

Secondly, the lowering of serum complement observed in certain instances may be a relative one due to the effect of anticomplementary substances in the serum. It has not previously been possible to estimate complement activity independently of any such anticomplementary influence, as only haemolytic methods for the estimation of serum complement have been available. Recently, Ellis and Gell (1958) have described a method for the estimation of one component of complement by a gel-diffusion precipitin technique which is independent of haemolytic activity and hence not influenced by anticomplementary substances in the serum.
It was therefore decided to investigate serum complement changes in a series of patients suffering from rheumatoid disease and systemic lupus erythematosus. In addition, a miscellaneous group comprising cases of scleroderma, dermatomyositis, and polyarteritis nodosa has been studied. It was hoped, by utilizing both the haemolytic and geldiffusion precipitin techniques, together with studies of anticomplementary activity, that conclusions could be reached regarding the absolute variations in serum complement activity in these conditions. Parallel studies of serum protein changes and the rheumatoid factor have been made.

\section{Materials and Methods}

Estimation of Serum Complement.-Titrations were made in a standardized haemolytic system and the 50 per cent. haemolysis end point was obtained from the linear graph relating the percentage haemolysis (converted into probit units) to the reciprocal of the corresponding serum dilution. A lyophilized standard reference serum was titrated in parallel with all sera to avoid errors arising from the use of different batches of sheep cells. The techniques used for the collection, handling, and storage of sera and details of this method have been previously described (Walton and Ellis, 1958). Estimations in a control series of 143 subjects gave values ranging from 0.95 to 2.05 units per $\mathrm{ml}$. serum, with a mean of 1.43 units and a standard deviation of 0.27 .

Estimation of Serum Anticomplementary Activity.Anticomplementary activity of sera was determined using heat inactivated sera $\left(56^{\circ} \mathrm{C}\right.$. for 20 minutes $)$. Sera so treated were added in various dilutions to a 1 in 10 dilution of a standard lyophilized human serum and sensitized sheep cells. The 50 per cent. haemolysis end point was obtained by relating the percentage inhibition of haemolysis to the logarithm of the concentration of test serum. This method was based on that previously described (Walton, Ellis, and Taylor, 1957) for the estimation of the anticomplementary activity of sulphated polysaccharides. 
Estimation of a Component of Complement $\left(\mathrm{C}_{\mathbf{1}}{ }^{1}\right)$.A rabbit antiserum to a component of human complement was prepared and a gel-diffusion precipitin technique (Gell, 1957) was used for the semi-quantitative estimation of this component in test sera as previously described (Ellis and Gell, 1958). Evidence now available suggests that this is the first component of complement, hereafter denoted as $C_{1}{ }^{1}$. Values for unknown sera were expressed as a percentage of a standard reference serum obtained from a healthy subject. Estimations in a control group of twenty healthy young adults gave values ranging from 87 to 150 per cent. (mean 111.8, standard deviation $18 \cdot 8$ ).

Demonstration of the "Rheumatoid Factor".-The "rheumatoid factor" was demonstrated by Ball's modification of the sensitized sheep-cell agglutination test of Rose-Waaler (Ball, 1950), but using the pattern of sedimentation in plastic cups as the index of agglutination. In addition, a ring-precipitin test in agar was used, the antigen being an 0.6 per cent. solution of human pooled gamma globulin (Lister Institute), denatured by heating at $63^{\circ} \mathrm{C}$. for ten minutes.

Estimation of Serum Proteins.-Total serum proteins were estimated by the Biuret method. Albumin and the individual globulin components were estimated by means of quantitative paper electrophoresis as described by Hardwicke (1954).

\section{Classification of Cases Studied}

Rheumatoid Disease.-It was considered of major importance at the outset to exclude all patients in whom the diagnosis of rheumatoid disease was doubtful. Criteria adopted for inclusion were based upon those described by Ropes, Bennett, Cobb, Jacox, and Jessar (1957), and correspond to the "Definite Rheumatoid Arthritis" group recommended in the 1958 revision of diagnostic criteria for rheumatoid arthritis by the American Rheumatism Association (Ropes, Bennett, Cobb, Jacox, and Jessar, 1959).

Cases were unselected in that they consisted of consecutive patients seen at the out-patients departments or wards in the United Birmingham and Birmingham Regional Hospitals. Over 100 cases of rheumatoid disease were originally studied, but in only 78 was the data adequate confidently to make the diagnosis for the present purpose. Cases were further subdivided into four groups, depending upon the stage of the disease (Steinbrocker, Traeger, and Batterman, 1949); Stage I, Early; Stage II, Moderate; Stage III, Severe; Stage IV, Terminal.

Systemic Lupus Erythematosus.-Eighteen cases of lupus erythematosus were studied (15 female and 3 male), of which fourteen had a widespread systemic involvement, two predominant polyarthritis and two mainly cutaneous manifestations. A total of fifteen had arthritis, nine cutaneous lesions, and $\bar{\beta}$ eight renal involvement. L.E. cells (Hargraves $\frac{\square}{\text { ? }}$ Richmond, and Morton, 1948) were found in seven:teen of the eighteen cases.

Miscellaneous Group.-A limited number of miscellaneous disorders-Still's disease ( 2 cases) $\overline{\frac{5}{5}}$. scleroderma (3 cases), dermatomyositis ( 1 case) $)_{\mathbb{\mathbb { D }}}$ and polyarteritis nodosa (4 cases)-was examined.

\section{Results}

\section{(1) Patients with Rheumatoid Disease}

(a) Serum Complement.-Estimations by the haemolytic method were made in 78 different patients at various stages of rheumatoid activity an in some instances repeated estimations were madein The results of the first value obtained in each caser studied, together with the corresponding sheep-celg agglutination titre, rheumatoid factor precipitintitre, and serum gamma globulin level, are showres in Table I (opposite).

The mean serum complement value for all cases is 1.72 units per $\mathrm{ml}$. (standard deviation 0.32 ) Comparison of this mean with the control group mean reveals a significant difference $(P<0 \cdot 001)$ 응

Fig. 1 (overleaf) shows that, although the mear complement level is raised and many patients hive raised serum complement values, many more âr within the normal range. It is therefore clear tha an isolated value obtained in a single patient is nog likely to be of diagnostic significance. It is og interest that one patient (Case 15, Table I) had very low value quite distinct from that obtaineof in the others. This is probably explained by the fact that the serum in this instance was markedly antio complementary-sufficiently so to produce a cal culated overall serum complement level of the orde $\overline{\text { E }}$ actually obtained. (A 1 in 12 dilution of the patient's serum produced 50 per cent. inhibition of a 1 in $1 \%$. dilution of normal serum at the time the patient'\$ serum complement was 0.45 units per ml.) Con firmatory evidence was obtained by using the gelo diffusion precipitin technique for the estimation of the $\mathrm{C}_{1}{ }^{1}$ component of complement which gave normal value of 100 per cent. Furthermore, seriak observations over a period of many months in this patient showed a gradual rise in serum complemenf activity from $0 \cdot 11$ to 0.85 units per ml. (as measured by the haemolytic method) and a loss of anticome plementary activity, but no change in the geto diffusion precipitin $C_{1}{ }^{1}$ value which remained at $8 \frac{5}{\sigma}$ to 100 per cent. One can therefore conclude that $\frac{0}{9}$ in this patient, the initial low serum complemento 
SERUM COMPLEMENT, RHEUMATOID FACTOR, AND SERUM PROTEINS

TABLE I

SERUM COMPLEMENT, SHEEP-CELL AGGLUTINATION TESTS, AND GAMMA GLOBULIN LEVELS IN 78 CASES

\begin{tabular}{|c|c|c|c|c|c|}
\hline $\begin{array}{l}\text { Stage } \\
\text { of } \\
\text { Disease }\end{array}$ & Case No. & $\begin{array}{l}\text { Serum } \\
\text { Complement } \\
\text { (Units per ml.) }\end{array}$ & $\begin{array}{c}\text { Sheep-Cell } \\
\text { Agglutination } \\
\text { Titre (Reciprocal) }\end{array}$ & $\begin{array}{c}\text { Precipitin } \\
\text { Test Titre } \\
\text { (Reciprocal) }\end{array}$ & $\begin{array}{c}\text { Serum } \\
\text { Gamma-Globulin } \\
\text { (g. per cent.) }\end{array}$ \\
\hline I & $\begin{array}{r}5 \\
10 \\
20 \\
24 \\
31 \\
37 \\
38 \\
39 \\
42 \\
76 \\
77 \\
78\end{array}$ & $\begin{array}{l}1.28 \\
1.81 \\
1.95 \\
1.96 \\
1.83 \\
1.59 \\
2.49 \\
2.18 \\
1.67 \\
1.87 \\
2.10 \\
2.05\end{array}$ & $\begin{array}{r}0 \\
128 \\
0 \\
0 \\
0 \\
32 \\
0 \\
0 \\
0 \\
0 \\
0 \\
0\end{array}$ & $\begin{array}{r}\mathbf{0} \\
20 \\
0 \\
0 \\
0 \\
0 \\
0 \\
0 \\
0 \\
0 \\
0\end{array}$ & $\begin{array}{c}1 \cdot 22 \\
2.08 \\
1.35 \\
1.00 \\
1.90 \\
1.54 \\
1.65 \\
0.99 \\
= \\
=\end{array}$ \\
\hline II & $\begin{array}{l}7 \\
11 \\
17 \\
23 \\
25 \\
28 \\
29 \\
32 \\
41 \\
47 \\
49 \\
51 \\
52 \\
53 \\
54 \\
55 \\
57 \\
60 \\
63 \\
67 \\
71 \\
43 \\
73\end{array}$ & $\begin{array}{l}1 \cdot 79 \\
1 \cdot 61 \\
1 \cdot 46 \\
2 \cdot 42 \\
1 \cdot 40 \\
2 \cdot 50 \\
2 \cdot 64 \\
2 \cdot 01 \\
1 \cdot 56 \\
1 \cdot 72 \\
1 \cdot 93 \\
1 \cdot 92 \\
1 \cdot 36 \\
1 \cdot 50 \\
1 \cdot 59 \\
1 \cdot 55 \\
1 \cdot 47 \\
1 \cdot 78 \\
1 \cdot 65 \\
1.93 \\
1 \cdot 78 \\
1 \cdot 72 \\
1 \cdot 52\end{array}$ & $\begin{array}{r}0 \\
128 \\
256 \\
0 \\
0 \\
0 \\
16 \\
128 \\
0 \\
0 \\
0 \\
512 \\
512 \\
512 \\
32 \\
0 \\
16 \\
512 \\
128 \\
64 \\
32 \\
256\end{array}$ & $\begin{array}{r}0 \\
10 \\
20 \\
0 \\
20 \\
0 \\
0 \\
0 \\
10 \\
0 \\
0 \\
0 \\
10 \\
0 \\
10 \\
0 \\
0 \\
2 \\
16 \\
4 \\
8 \\
16\end{array}$ & $\begin{array}{c}1 \cdot 54 \\
0.80 \\
0.68 \\
1.53 \\
1 \cdot 10 \\
2.78 \\
2 \cdot 33 \\
1.39 \\
1.27 \\
1.73 \\
2.46 \\
2 \cdot 10 \\
1.66 \\
1.41 \\
1.29 \\
2.00 \\
0.90 \\
2.04 \\
= \\
= \\
= \\
-\end{array}$ \\
\hline III & $\begin{array}{l}1 \\
6 \\
13 \\
18 \\
19 \\
33 \\
34 \\
35 \\
36 \\
44 \\
45 \\
50 \\
56 \\
58 \\
59 \\
61 \\
62 \\
65 \\
66 \\
68 \\
74 \\
75 \\
76 \\
77\end{array}$ & $\begin{array}{l}1 \cdot 35 \\
1 \cdot 41 \\
1 \cdot 72 \\
1 \cdot 89 \\
1 \cdot 40 \\
1 \cdot 68 \\
1 \cdot 09 \\
1 \cdot 89 \\
2 \cdot 00 \\
1 \cdot 55 \\
1 \cdot 98 \\
1 \cdot 70 \\
1 \cdot 57 \\
1 \cdot 50 \\
1 \cdot 68 \\
1 \cdot 46 \\
1 \cdot 19 \\
1 \cdot 80 \\
2 \cdot 20 \\
1 \cdot 03 \\
1 \cdot 82 \\
1 \cdot 50 \\
1 \cdot 55 \\
1 \cdot 13\end{array}$ & $\begin{array}{r}512 \\
64 \\
64 \\
256 \\
1.024 \\
0 \\
256 \\
1,024 \\
0 \\
512 \\
256 \\
0 \\
0 \\
256 \\
0 \\
32 \\
128 \\
0 \\
512 \\
4,096 \\
128 \\
8,192 \\
64 \\
512\end{array}$ & $\begin{array}{r}16 \\
0 \\
5 \\
10 \\
40 \\
0 \\
8 \\
10 \\
0 \\
20 \\
10 \\
0 \\
0 \\
2 \\
0 \\
0 \\
0 \\
20 \\
64 \\
2 \\
32 \\
0 \\
8\end{array}$ & $\begin{array}{c}1 \cdot 41 \\
1 \cdot 61 \\
1 \cdot 89 \\
1 \cdot 35 \\
1 \cdot 61 \\
= \\
2.43 \\
1 \cdot 26 \\
1 \cdot 57 \\
1 \cdot 14 \\
1 \cdot 66 \\
1 \cdot 50 \\
1 \cdot 61 \\
1.92 \\
1 \cdot 70 \\
0 \cdot 58 \\
2 \cdot 13 \\
= \\
- \\
= \\
= \\
-\end{array}$ \\
\hline IV & $\begin{array}{c}2 \\
3 \\
4 \\
8 \\
9 \\
12 \\
15 * \\
16 \\
21 \\
22 \\
26 \\
27 \\
30 \\
40 \\
46 \\
64 \\
69 \\
70 \\
72\end{array}$ & $\begin{array}{l}1 \cdot 45 \\
2.21 \\
1.92 \\
1.90 \\
1.54 \\
1.69 \\
0.11 \\
1.63 \\
1.35 \\
1.64 \\
1 \cdot 74 \\
2 \cdot 16 \\
1.47 \\
1.91 \\
1.57 \\
1.54 \\
1.33 \\
1.65 \\
1.91\end{array}$ & $\begin{array}{r}256 \\
512 \\
512 \\
64 \\
64 \\
0 \\
1,024 \\
128 \\
0 \\
512 \\
0 \\
32 \\
128 \\
256 \\
128 \\
512 \\
512 \\
2,048 \\
1,024\end{array}$ & $\begin{array}{r}10 \\
10 \\
32 \\
8 \\
20 \\
0 \\
40 \\
0 \\
0 \\
10 \\
0 \\
2 \\
10 \\
10 \\
10 \\
20 \\
4 \\
16 \\
8\end{array}$ & $\begin{array}{l}1 \cdot 37 \\
1 \cdot 42 \\
1 \cdot 89 \\
1 \cdot 39 \\
1 \cdot 08 \\
2 \cdot 15 \\
1 \cdot 75 \\
3 \cdot 10 \\
1 \cdot 43 \\
1 \cdot 23 \\
2 \cdot 90 \\
1 \cdot 76 \\
2 \cdot 27 \\
2 \cdot 20 \\
2 \cdot 00 \\
1 \cdot 24 \\
= \\
=\end{array}$ \\
\hline
\end{tabular}

* Serum markedly anticomplementary. This case was excluded from the analysed data and from Fig. 1. 


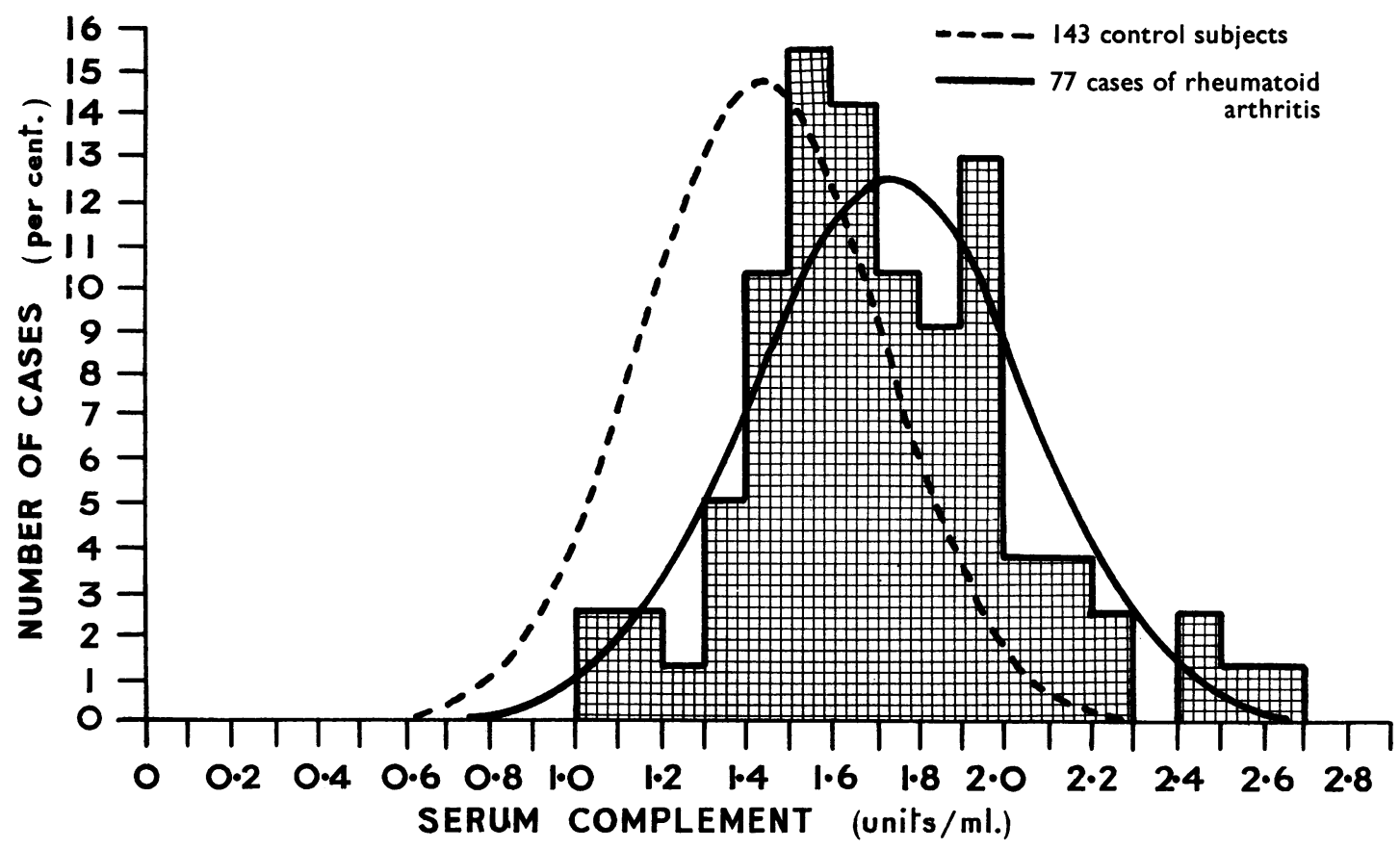

Fig. 1.-Distribution of serum complement in 77 cases of rheumatoid disease (Superimposed interrupted and continuous curves represent calculated normal distributions for 143 control subjects and 77 cases of rheumatoid disease, respectively).

value was not due to an absolute reduction. No other case of rheumatoid disease had a serum which was significantly anticomplementary.

The $\mathrm{C}_{1}{ }^{1}$ component of complement was estimated in a further twenty cases of rheumatoid disease and the values obtained ranged from 75 to 200 per cent. when compared with the reference serum (mean 145 per cent., standard deviation 43 per cent.). Comparison of this mean with that of the control group confirms that there is a significant elevation of the $\mathrm{C}_{1}{ }^{1}$ component in rheumatoid disease $(P<0.01)$.

All cases of rheumatoid disease were subdivided into the four stages previously described. The results obtained are summarized in Tables IIA and IIв (opposite), which show that there is an overall tendency for the serum complement to become less elevated in successive stages (correlation coefficient $(r)=-0.241 ; P<0.05,>0 \cdot 02)$. This suggests that serum complement is elevated during the earlier stages of rheumatoid disease, but returns towards the normal range as the disease progresses.

(b) Variations in Serum Gamma Globulin Levels.The levels were estimated in 58 cases, and 67 per cent. were found to have a value above the upper limit of normal $(1 \cdot 4 \mathrm{~g}$. per cent.). Elevated levels occur in 50,61, 75, and 73 per cent. of cases 훙응 Stages I, II, III, and IV respectively. There is also a tendency towards a higher serum gamma globulin $\overline{0}$ level in successive stages (correlation coefficient $(r) \stackrel{2}{\circ}$ $=+0.226, P<0 \cdot 10,>0 \cdot 05)$.

(c) Sensitized Sheep-cell Agglutination.-64.1 per $\frac{\overline{\overrightarrow{0}}}{3}$ cent. of patients have positive sensitized sheep-cell $\vec{D}$ agglutination tests; $16 \cdot 7,60 \cdot 9,75$, and $84 \cdot 2$ per후 cent. in Stages I, II, III, and IV respectively. There is a significant positive correlation between the sensitized sheep-cell agglutination titres and the four stages of disease activity (correlation coefficient $(r)=+0.394 ; P<0.001)$.

There is also a significant negative correlation between this factor and serum complement activity 은 $(r=-0.557 ; P<0.001)$. This is not necessarily a causal relationship, but supports the concept that serum complement is less markedly elevated in the advanced stages of the disease whilst the rheumatoid o factor is increased.

(d) Precipitin Test for Rheumatoid Factor.Although fewer positive results were obtained with this test, the distribution pattern follows that for the $\frac{0}{0}$ sensitized sheep-cell agglutination. 53.9 per cent. $\stackrel{\text { \& }}{\rightarrow}$ of cases have positive tests; $8 \cdot 3,50 \cdot 0,60 \cdot 9$, and $78 \cdot 9^{\circ}$ 
SERUM COMPLEMENT, RHEUMATOID FACTOR, AND SERUM PROTEINS

TABLE IIA

SERUM COMPLEMENT IN THE FOUR STAGES OF RHEUMATOID DISEASE AND IN THE CONTROL GROUP

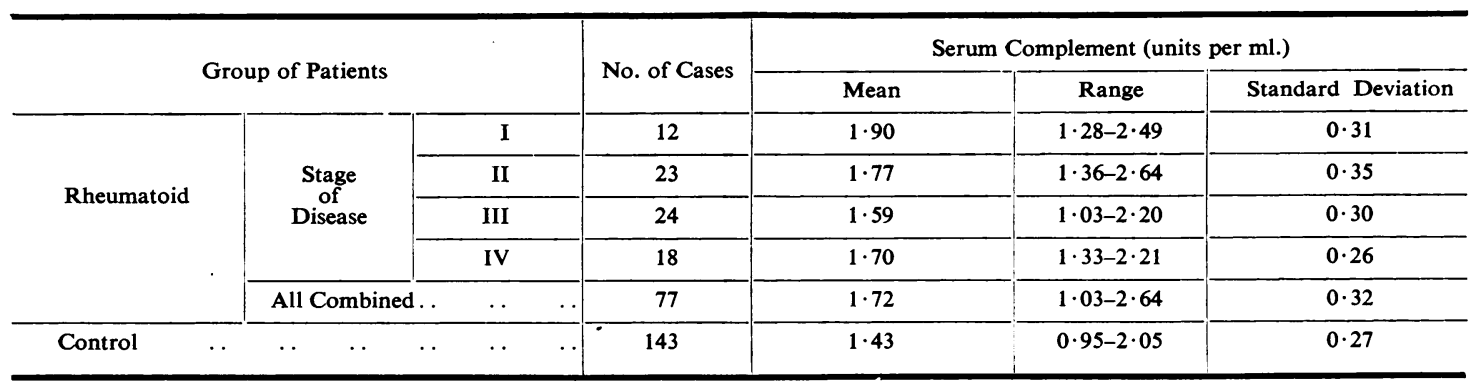

TABLE IIB

SERUM COMPLEMENT AND RHEUMATOID FACTOR IN THE FOUR STAGES OF RHEUMATOID DISEASE

\begin{tabular}{|c|c|c|c|}
\hline Correlations Examined & $\begin{array}{l}\text { Total Number of } \\
\text { Observations }(n)\end{array}$ & Coefficient $(r)$ & $(P)$ \\
\hline Serum Complement and Stage of Disease $\quad \ldots \quad \ldots$ & 77 & $-0 \cdot 241$ & $\begin{array}{l}<0.05 \\
>0.02\end{array}$ \\
\hline Serum Gamma-Globulin and Stage of Disease .. & 58 & $+0 \cdot 226$ & $\begin{array}{l}<0 \cdot 10 \\
>0 \cdot 05\end{array}$ \\
\hline $\begin{array}{c}\text { Rheumatoid Factor* (Sensitized Sheep-cell Agglutina- } \\
\text { tion) and Stage of Disease } \ldots \\
\end{array}$ & 76 & $-0 \cdot 394$ & $<0.001$ \\
\hline 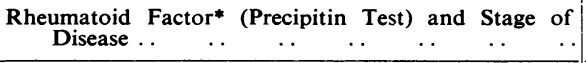 & 75 & $+0 \cdot 320$ & $<0.01$ \\
\hline $\begin{array}{c}\text { Serum Complement and Rheumatoid Factor* (Sensi- } \\
\text { tized Sheep-cell Agglutination) } \\
\end{array}$ & 76 & -0.557 & $<0.001$ \\
\hline \begin{tabular}{cccccc}
\multicolumn{3}{c}{ Serum Complement and Rheumatoid Factor* (Precipi- } \\
tin Test) & $\ldots$ & $\ldots$ & $\ldots$ & $\ldots$ & $\ldots$
\end{tabular} & 74 & $-0 \cdot 712$ & $<0.001$ \\
\hline
\end{tabular}

* Reciprocal of serum dilutions in the sensitized sheep-cell agglutination and precipitin tests, transformed to a logarithmic scale for calculation of correlation coefficients.

per cent. in Stages I, II, III and IV, respectively $(r=+0.320 ; P<0.01)$.

A significant negative correlation also exists between serum complement and rheumatoid factor estimated by this technique $(r=-0.712$; $P<0 \cdot 001)$. See Table IIB.

\section{(2) Patients with Systemic Lupus Erythematosus}

(a) Serum Complement.-This was estimated in eighteen patients with systemic lupus erythematosus (Table III, overleaf).

The values obtained varied from zero serum complement activity to 1.73 units per $\mathrm{ml}$. The distribution is further illustrated and compared with the control group distribution in Fig. 2 (overleaf).

Cases 91, 92, and 93 were receiving steroid therapy and were in remission at the time of study. The remaining patients were active, although several had been under treatment with steroids for varying periods of time (see Table III for details).

Excluding the three inactive cases, the values obtained ranged from zero to $1 \cdot 31$ units per $\mathrm{ml}$. (mean 0.56 , a standard deviation 0.47 ). This mean is significantly different from that of the control group $(P<0 \cdot 001)$.

Nine patients had a serum which was anticomplementary, and this was most marked in Cases 82, 83,85 , and 87 , with serum complement values of zero, 0.08 , and $0 \cdot 11$ units per ml. respectively. The degree of anticomplementary activity, however, did not appear to be sufficient to account for all the serum complement depression. Estimations of the $\mathrm{C}_{1}{ }^{1}$ component by the gel-diffusion precipitin technique in six cases gave low values (see Table III) from 6 to 62 per cent., except in Case 90 (150 per cent.). This shows that there is an absolute reduction in complement concentration in systemic lupus erythematosus.

Complement was found to be low in systemic lupus erythematosus whichever system was clinically predominantly affected. For example, comparable values were obtained in Case 85 (predominant cutaneous lesions), Case 83 (joint, renal, and cardiovascular lesions, but no cutaneous manifestations), 
TABLE III

CLINICAL DETAILS OF EIGHTEEN CASES OF SYSTEMIC LUPUS ERYTHEMATOSUS

\begin{tabular}{|c|c|c|c|c|c|c|c|}
\hline \multirow[b]{2}{*}{$\begin{array}{l}\text { Case } \\
\text { No. }\end{array}$} & \multirow[b]{2}{*}{ Sex } & \multirow[b]{2}{*}{ Age } & \multirow[b]{2}{*}{ Main Clinical Features } & \multirow[b]{2}{*}{$\begin{array}{l}\text { L.E.-Cell } \\
\text { Test }\end{array}$} & \multicolumn{2}{|c|}{ Serum Complement } & \multirow[b]{2}{*}{ Remarks } \\
\hline & & & & & $\begin{array}{c}\text { Haemolytic } \\
\text { Method (Cl) } \\
\text { (units per ml.) }\end{array}$ & $\begin{array}{l}\text { Gel-Diffusion } \\
\text { Method }\left(\mathrm{C}_{1} \mathbf{1}\right) \\
\text { (per cent.) }\end{array}$ & \\
\hline 79 & $\mathbf{F}$ & 36 & $\begin{array}{l}\text { Polyarthritis, Raynaud's Phenomenon, } \\
\text { Nephritis, Fever } \\
\text { No Cutaneous Lesions }\end{array}$ & Positive & $0 \cdot 70$ & & $\begin{array}{l}\text { Serum Anticomplementary } \\
\text { Had received ACTH for One } \\
\text { week }\end{array}$ \\
\hline 80 & $\mathrm{~F}$ & 37 & $\begin{array}{l}\text { Polyarthritis, Facial Rash, Nephrotic } \\
\text { Syndrome }\end{array}$ & Positive & $0 \cdot 18$ & & $\begin{array}{l}\text { Serum Anticomplementary } \\
\text { Not on Steroids }\end{array}$ \\
\hline 81 & $\mathbf{F}$ & 35 & $\begin{array}{l}\text { Polyarthritis, Facial Rash, Nephrotic } \\
\text { Syndrome }\end{array}$ & Positive & $0 \cdot 30$ & 50 & $\begin{array}{l}\text { Serum Anticomplementary } \\
\text { On Cortisone } \\
\text { Active }\end{array}$ \\
\hline 82 & $\mathbf{F}$ & 66 & $\begin{array}{l}\text { Polyarthritis } \\
\text { Cutaneous Lesions Face and Digits }\end{array}$ & Negative & 0 & & $\begin{array}{l}\text { Serum Anticomplementary } \\
\text { On Cortisone } \\
\text { Active }\end{array}$ \\
\hline 83 & $\mathbf{F}$ & 46 & $\begin{array}{l}\text { Polyarthritis, Pericarditis, Pleurisy } \\
\text { No Cutaneous Lesions }\end{array}$ & Positive & 0 & & $\begin{array}{l}\text { Serum Anticomplementary } \\
\text { Not on Steroids }\end{array}$ \\
\hline 84 & $\mathbf{F}$ & 47 & $\begin{array}{l}\text { Polyarthritis } \\
\text { No Renal or Cutaneous Lesions }\end{array}$ & Positive & $1 \cdot 10$ & & $\begin{array}{l}\text { Serum not Anticomplementary } \\
\text { Not on Steroids }\end{array}$ \\
\hline 85 & $\mathbf{F}$ & 39 & $\begin{array}{l}\text { Cutaneous Lesions Face and Digits } \\
\text { Polyarthritis } \\
\text { No Renal Involvement }\end{array}$ & Positive & 0.08 & & $\begin{array}{l}\text { Serum Anticomplementary } \\
\text { Not on Steroids }\end{array}$ \\
\hline 86 & $\mathbf{F}$ & 33 & $\begin{array}{l}\text { Polyarthritis, Raynaud's Phenomenon, } \\
\text { Lung involvement }\end{array}$ & Positive & $0 \cdot 73$ & 25 & $\begin{array}{l}\text { Serum not Anticomplementary } \\
\text { Not on Steroids }\end{array}$ \\
\hline 87 & $\mathbf{M}$ & 28 & $\begin{array}{l}\text { Presented as Pyrexia of Unknown Origin } \\
\text { Renal Involvement } \\
\text { No Arthritis or Cutaneous Lesions }\end{array}$ & Positive & $0 \cdot 11$ & 6 & $\begin{array}{l}\text { Serum Anticomplementary } \\
\text { Not on Steroids }\end{array}$ \\
\hline 88 & $\mathbf{M}$ & 46 & $\begin{array}{l}\text { Polyarthritis, Renal Involvement } \\
\text { No Cutaneous Lesions }\end{array}$ & Positive & 0.50 & & $\begin{array}{l}\text { Serum Anticomplementary } \\
\text { On Steroids } \\
\text { Active }\end{array}$ \\
\hline 89 & $\mathbf{F}$ & 34 & $\begin{array}{l}\text { Polyarthritis, Pleurisy } \\
\text { No Cutaneous or Renal Lesions }\end{array}$ & Positive & $1 \cdot 03$ & & $\begin{array}{l}\text { Serum not Anticomplementap } \\
\text { Not on Steroids }\end{array}$ \\
\hline 90 & $\mathbf{M}$ & 53 & $\begin{array}{l}\text { Polyarthritis, Pleurisy, Pericarditis, } \\
\text { Peripheral Neuritis, Raynaud's Pheno- } \\
\text { menon }\end{array}$ & Positive & $1 \cdot 31$ & 150 & $\begin{array}{l}\text { Serum not Anticomplementary } \\
\text { On Steroids } \\
\text { Active }\end{array}$ \\
\hline 91 & $\mathbf{F}$ & 29 & $\begin{array}{l}\text { Polyarthritis, Cutaneous and Renal } \\
\text { Lesions }\end{array}$ & Positive & $1 \cdot 73$ & & $\begin{array}{l}\text { Serum not Anticomplementary } \\
\text { On Steroids } \\
\text { Inactive }\end{array}$ \\
\hline 92 & $\mathbf{F}$ & 33 & $\begin{array}{l}\text { Cutaneous Lesions Face and Digits, } \\
\text { Pericarditis, Pleurisy }\end{array}$ & Positive & $1 \cdot 65$ & & $\begin{array}{l}\text { Serum not Anticomplementary } \\
\text { On Steroids } \\
\text { Inactive }\end{array}$ \\
\hline 93 & $\mathbf{F}$ & 35 & $\begin{array}{l}\text { Polyarthritis } \\
\text { No Renal or Cutaneous Lesions }\end{array}$ & Positive & $1 \cdot 51$ & & $\begin{array}{l}\text { Serum not Anticomplementary } \\
\text { On Steroids } \\
\text { Inactive }\end{array}$ \\
\hline 94 & $\mathbf{F}$ & 32 & $\begin{array}{c}\text { Polyarthritis, Facial Rash, Pleurisy, } \\
\text { Renal Involvement }\end{array}$ & Positive & $1 \cdot 08$ & & $\begin{array}{l}\text { Serum not Anticomplementary } \\
\text { On Steroids } \\
\text { Active }\end{array}$ \\
\hline 95 & $\mathbf{F}$ & 50 & $\begin{array}{l}\text { Pulmonary and Renal Involvement } \\
\text { No Arthritis or Cutaneous Lesions }\end{array}$ & Positive & $0 \cdot 10$ & 37 & $\begin{array}{l}\text { Serum Anticomplementary } \\
\text { Not on Steroids } \\
\text { Active }\end{array}$ \\
\hline 96 & $\mathbf{F}$ & 64 & $\begin{array}{l}\text { Cutaneous Lesions, Pleurisy } \\
\text { No Arthritis or Renal Involvement }\end{array}$ & Positive & $1 \cdot 19$ & 62 & Serum not Anticomplementary \\
\hline
\end{tabular}

and Case 87 (severe widespread involvement except in the joints). It is possible that Case 84 should be regarded as one of rheumatoid disease with a positive L.E.-cell test; if so, the normal complement value would support this. On the other hand, Case 90 had a normal complement value whilst suffering from undoubted active systemic lupus erythematosus, N although this patient had been receiving steroidso for 2 years. The highest complement value obro tained in an untreated active case of systemic lupus erythematosus was 1.03 units per ml. (Case $89, \stackrel{\infty}{?}$ Table III). 


\section{NORMAL DISTRIBUTION}

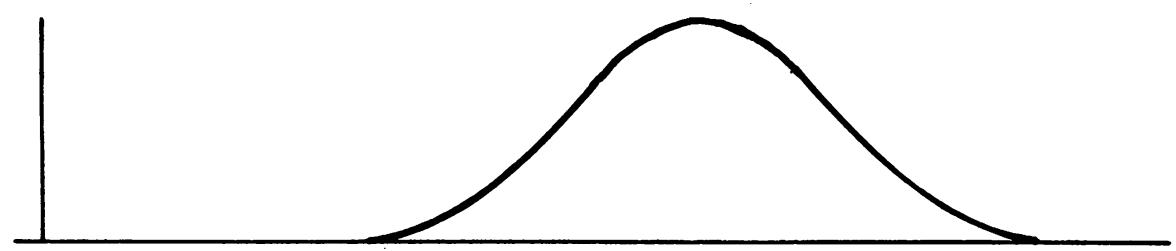

SYSTEMIC LUPUS ERYTHEMATOSUS

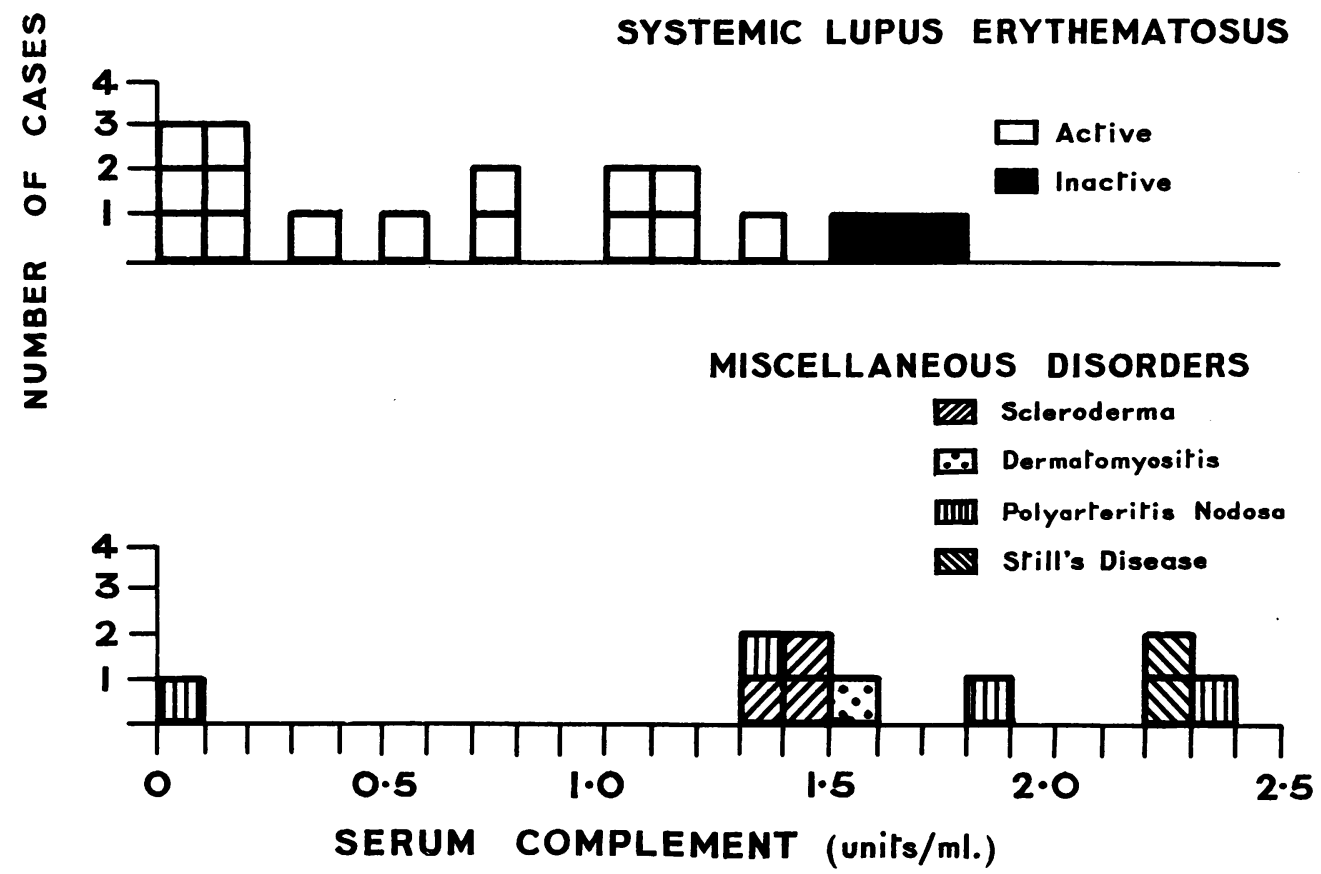

Fig. 2.-Serum complement levels in systemic lupus erythematosus and other disorders.

(b) Changes in Serum Gamma Globulin.-In twelve cases the serum proteins were studied by the quantitative paper electrophoresis technique. The gamma globulin was found to be almost consistently elevated, values ranging from $1 \cdot 2$ to $4 \cdot 6 \mathrm{~g}$. per cent. (upper limit of normal $1.4 \mathrm{~g}$. per cent.). There was, however, no significant correlation between the levels of albumin or individual globulin components and those of serum complement.

(c) Serial Changes in Serum Complement.Case 84 (Table III) was followed for one year. There was a remarkable clinical recovery in response to intensive cortisone therapy and the serum complement rose from 0.11 to 0.96 units per $\mathrm{ml}$. The serum anticomplementary activity gradually diminished and there was also a rise in the $C_{1}^{1}$ component measured by the gel-diffusion precipitin technique. This case has been previously described and illustrated (see Ellis and Walton, 1958, Fig. 6).

\section{(3) Miscellaneous Disorders}

(a) Still's Disease.-Serum complement was estimated in two cases and high values $(2 \cdot 23$ and $2 \cdot 25$ units per ml.) were obtained. One case was complicated by secondary amyloidosis.

(b) Scleroderma and Dermatomyositis.-Three cases of scleroderma were found to have values within the normal range $(1 \cdot 40,1 \cdot 30$, and $1 \cdot 40$ units per $\mathrm{ml}$.). A single case of dermatomyositis also had a normal value at 1.51 units per $\mathrm{ml}$.

(c) Polyarteritis Nodosa.-In three cases, values 
of $1 \cdot 35,1 \cdot 83$, and $2 \cdot 38$ units per $\mathrm{ml}$. respectively were obtained. In the fourth case, with marked renal involvement, there was a considerable depression of serum complement activity when measured by the haemolytic method $(0.05$ units per $\mathrm{ml}$.). After the serum had been kept at $4^{\circ} \mathrm{C}$., a cryoglobulin (Lerner and Watson, 1947) separated. This cryoglobulin was actively anticomplementary, and the serum showed a rise in complement activity when it was removed. Furthermore, when it was added to normal serum, a depression in complement activity occurred. A normal value was obtained in this case for the $\mathrm{C}_{1}{ }^{1}$ component of complement estimated by the gel-diffusion precipitin technique.

The results obtained in the miscellaneous group are illustrated in Fig. 2.

\section{Discussion}

The finding of a raised serum complement level in rheumatoid disease by both the haemolytic and the precipitin methods lends further support to the findings of Vaughan, Bayles, and Favour (1951a), and Williams and Law (1958). In the single case with a depressed serum complement level (as measured by the haemolytic method), it was possible to demonstrate that this was not an absolute lowering but an apparent one brought about by the presence of an anticomplementary substance in the serum. The new gel-diffusion precipitin technique for the estimation of the $\mathrm{C}_{1}{ }^{1}$ component of human complement, independently of anticomplementary activity, proved to be of particular value in this instance.

In the active untreated cases of systemic lupus erythematosus studied, it was confirmed that serum complement was low. By utilizing the gel-diffusion precipitin technique for the estimation of the $C_{1}{ }^{1}$ component, it was possible to demonstrate that, although several of the sera were anticomplementary, there was a true reduction in serum complement concentration.

Of the miscellaneous cases studied, the two patients with Still's disease had high values, and the three with scleroderma and one with dermatomyositis had normal values. Two cases of polyarteritis nodosa had normal values and a third an elevated one. A fourth was unusual in that there was relative reduction in complement due to the presence of an anticomplementary cryoglobulin.

\section{Diagnostic Value of Serum Complement}

Although one can demonstrate a significant elevation in the mean serum complement in rheuma- toid disease, many individual cases have values falling within the normal range. For this reason such estimations have a limited diagnostic value. On the other hand, the finding of a low serum complement supports a diagnosis of systemic lupus $\stackrel{5}{\rightarrow}$ erythematosus, though it is not diagnostic. In acute nephritis, for example, it is well known that $\frac{\overline{\bar{D}}}{\mathrm{n}}$ serum complement is depressed (Gunn, 1914-15; $\frac{\text { क }}{\widehat{D}}$ Kellett, 1936; Reader, 1948; Ellis and Walton, $\stackrel{\varnothing}{\varrho}$ 1958). The value obtained must therefore be interpreted in relation to the clinical features and the $\vec{\theta}$ other laboratory data.

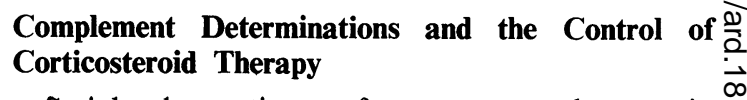

Serial observations of serum complement in $\dot{\omega}$ rheumatoid disease have no obvious value in the ${ }_{-}^{N}$ management of patients. Such observations are, $\mathrm{G}$ however, useful in systemic lupus erythematosus, $\frac{\circ}{?}$ where there is an initial low serum complement. $\vec{P}$ A rise in complement after steroid therapy can occur $\mathbb{D}$ before there are other signs of improvement, and a $\frac{\bar{\Phi}}{\mathbb{D}}$ persistently low level in a case treated with steroids $\stackrel{\mathbb{7}}{3}$ may be an indication that dosage is inadequate. $\mathbb{\mathbb { Q }}$ Repeated estimations are therefore useful in occasional cases when a decision has to be made on level of dosage or the duration of its administration.

\section{Mechanisms of Complement Variation}

Little is known concerning the mechanism of variations in serum complement in different disease $\stackrel{\square}{\unrhd}$ states. An increase in activity in rheumatoid $\overrightarrow{\vec{O}}$ disease may be interpreted as a non-specific pheno- 3 menon occurring in response to the inflammatory process. High levels are similarly found in cases of erysipelas, scarlet fever and pneumococcal infections (Ecker, Seifter, Dozois, and Barr, 1946). 응 Furthermore, the tissue damage need not neces- $\frac{0}{3}$ sarily be of infective origin, for raised levels have also been reported in myocardial infarction (Boltax and Fischel, 1956). The elevation of levels in

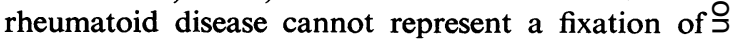
complement by antigen-antibody reactions in vivo. $\rightarrow$ Nevertheless, this does not necessarily preclude an underlying immunological mechanism.

The low levels which are found in systemic lupus erythematosus theoretically might occur as a result of three different mechanisms:

(i) Diminished production;

(ii) Interaction with circulating anticomplementary substances;

(iii) Increased utilization, in particular in immune? reactions. 
Diminished production is of course possible, but little is known of the method of formation of complement in health or disease.

With regard to the lowering of serum complement by anticomplementary substances, it has been possible in the present study to demonstrate that in systemic lupus erythematosus, although the serum may be anticomplementary, there is also a true reduction in serum complement. However, anticomplementary activity played the major part in the apparent lowering of serum complement in one case of rheumatoid disease (Case 15, Table I), and in the case of polyarteritis nodosa with cryoglobulinaemia.

The third hypothesis, that of excessive utilization, is an attractive one and is consistent with current knowledge of immune reactions in systemic lupus erythematosus. It is known that complement may be fixed during the interaction of antigen and antibody in vivo (Stavitsky, Hackel, and Heymann, 1954) and depressions of serum complement activity have been observed in serum sickness and penicillin reactions (Elliott and Mathieson, 1953). It appears to be established that the L.E.-cell phenomenon itself is due to the presence of an auto-antibody directed against the leucocyte nucleus (Nathan and Snapper, 1958). By the use of the fluorescent antibody technique it has been shown that sera from patients with lupus erythematosus contain an abnormal gamma globulin which combines with intranuclear deoxyribonucleoprotein (Holborow, Weir, and Johnson, 1957; Bardawil, Toy, Galins, and Bayles, 1958). Furthermore, complement fixation has been shown to occur during the reaction of the serum gamma globulin component with cell nuclei, nucleoproteins and deoxyribonucleic acid in patients suffering from lupus erythematosus (Robbins, Holman, Deicher, and Kunkel, 1957; Pearson, Craddock, and Simmons, 1958). The lowering of complement in vivo might therefore result from these widespread antigen-antibody reactions occurring throughout the small blood vessels of the affected organs (Dameshek, 1958).

\section{The Rheumatoid Factor and its Relation to Serum Complement}

Since Cecil, Nicholls, and Stainsby (1930) first observed that the sera from patients with rheumatoid arthritis were capable of agglutinating streptococci, much progress has been made in our knowledge of the responsible "rheumatoid factor". We have used Ball's modification of the Rose-Waaler Test (Waaler, 1940; Rose, Ragan, Pearce, and Lipman, 1948; Ball, 1950) for the demonstration of the rheumatoid factor in the present series, and have found a negative correlation between levels of serum complement and this factor. This relationship was confirmed using a gel-precipitin method to demonstrate the rheumatoid factor and is evidence that serum complement levels become less elevated as the rheumatoid activity progresses and as the rheumatoid factor concentration in the serum is increasing.

It is known that the rheumatoid factor is an S19 gamma globulin and that, whilst it has some of the physico-chemical and immunological features of S19 antibodies, other properties resemble those of complement. It is not, however, one of the known components of the complement-properdin system (Edelman, Kunkel, and Franklin, 1958). In the present study the negative correlation between complement and rheumatoid factor is further evidence that they are distinct.

It has been shown that antibody which flocculates rapidly fixes complement (Hill and Osler, 1955) and, although we have observed that complement is not essential for the interaction of rheumatoid factor and aggregated gamma globulin, it is possible that it may still be precipitated in the presence of the insoluble antigen-antibody complex. This may explain the return of complement levels towards normal during the course of rheumatoid disease, when the rheumatoid factor is increasing.

\section{Summary}

Serum complement estimations have been performed in 106 patients suffering from rheumatoid disease ( 78 cases), systemic lupus erythematosus (18 cases), and several miscellaneous disordersdermatomyositis, scleroderma, and polyarteritis nodosa (10 cases).

In rheumatoid disease, although many cases have raised serum complement levels, a number have values within the normal range. The mean for all cases of rheumatoid disease is significantly raised compared with the mean for 143 control subjects. There is a negative correlation between serum complement levels and those of rheumatoid factor estimated by sensitized sheep-cell agglutination or by a precipitin technique. A single case of rheumatoid disease in which the serum complement level was low is attributed to the presence of anticomplementary substances in the serum.

In active untreated systemic lupus erythematosus, serum complement is depressed and this is considered to be a true reduction in concentration not fully accounted for by the presence of anticomplementary substances. This concept is supported by the application of a new gel-diffusion precipitin technique for the estimation of a component of complement. 
The elevation of serum complement in rheumatoid disease is thought to be a non-specific reaction to the inflammatory process, whereas the depression in lupus erythematosus is consistent with an underlying immune mechanism involving in vivo complementfixing antigen-antibody reactions.

We wish to acknowledge with gratitude the co-operation of Dr. C. F. Hawkins and other physicians of the United Birmingham Hospitals. We are indebted to Professor J. R. Squire for his criticism and advice, to Dr. J. F. Soothill for collaborating with the gel-diffusion precipitin technique, and to Misses $M$. Phillips and A. Hudson for their valuable technical assistance. One of us (H.A.E.) was in receipt of a research grant from the United Birmingham Hospital Endowment Fund during the time this study was undertaken. The work was supported in part by a grant from the Empire Rheumatism Council.

\section{REFERENCES}

Ball, J. (1950). Lancet, 2, 520.

Bardawil, W. A., Toy, B. L., Galins, N., and Bayles, T. B. (1958). Amer. J. Path., 34, 607 .

Boltax, A. J., and Fischel, E. E. (1956). Amer. J. Med., 20, 418.

Cecil, R. L., Nicholls, E. E., and Stainsby, W. J. (1930). Amer. J. Path., 6, 619.

Dameshek, W. (1958). Ann. intern. Med., 48, 707.

Ecker, E. E. Seifter, S., Dozois, T. F., and Barr, L. (1946). J. clin. Invest., 25, 800.

Edelman, G. M.. Kunkel, H. G., and Franklin, E. C. (1958). J. exp. Med., 108, 105 .

Elliott, J. A., and Mathieson, D. R. (1953). A.M.A. Arch. Derm. Syph., 68, 119

Ellis, H. A., and Geli, P. G. H. (1958) Nature (Lond.), 181. 1667

and Walton, K. W. (1958). Immunology, 1, 234

Gell, P. G. H. (1957). J. clin. Path., 10, 67.

Gell, P. G. H. (1957). J. clin. Path., 10, 67. 155.

Hardwicke, J. (1954). Biochem. J., 57, 166.

Hargraves, M. M., Richmond, H., and Morton, R. (1948). Proc. Mayo Clin, 23, 25.

Hill, B. M., and Osler, A. G. (1955). J. Immunol., 75, 146.

Holborow, E. J., Weir, D. M., and Johnson, G. D (1957). Brit. med. J., 2, 732.

Kellett, C. E. (1936). Lancet, 2, 1262.

Lerner, A. B., and Watson, C. J. (1947). Amer. J. med. Sci., 214, 410. Nathan, D. J., and Snapper, I. (1958). Blood, 13, 883.

Pearson, C. M.. Craddock, C. G., and Simmons, N. S. (1958). J. Lab. clin. Med., 52, 580.

Rachmilewitz, M., and Silberstein, W. (1937). Ibid., 22, 1241.

Reader, R. (1948). Brit. J. exp. Path., 29, 255.

Robbins, W. C. Holman, H. R., Deicher, H., and Kunkel, H. G. (1957). Proc. Soc. exp. Biol., 96, 575.

Ropes, M.W., Bennett, G. A., Cobb, S., Jacox, R., and Jessar, R. A. (1957) J. chron. Dis., 3, 630.

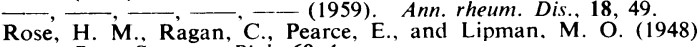
Proc. Soc. exp. Biol., 68, 1

Stavitsky, A. B., Hackel, D. B., and Heymann, W. (1954). Ibid., 85,593 .

Steinbrocker, O., Traeger, C. H., and Batterman, R. C. (1949). J. Amer. med. Ass., 140, 659

Vaughan, J. H., Bayles, T. B., and Favour, C. B. (1951a). Amer. J. med. Sci., 222, 186

T., . med. 222, (1951b). J. Lab. clin. Med., 37, 698

Waale, E. (1940). Acta path. microbiol. scand., 17, 172.

Walton, K. W. and Ellis, H. A. (1958). Immunology, 1, 224

Wand Taylor, C. E. D. (1957). Brit J. exp. Path., 38, 237.

Williams, R. C., and Law, D. H. (1958). J. Lab. clin. Med., 52, 273.

Complément sérique, facteur rhumatismal et autres protéines sériques dans la maladie rhumatismale et le lupus érythémateux disséminé

RÉSUMÉ

Le complément sérique fut dosé chez 106 malades, dont 78 atteints de maladie rhumatismale, 18 de lupus érythémateux disséminé et 10 souffrant de troubles divers, tels que dermatomyosite, sclérodermie et poly- $\overline{3}$ artérite noueuse.

Dans la maladie rhumatismale, bien que beaucoup de cas ont un titre du complément sérique élevé, d'autres ont un titre normal. La moyenne pour tous les cas de $\overrightarrow{\bar{\sigma}}$ maladie rhumatismale est appréciablement élevée, en comparaison à la moyenne chez 143 témoins. Il y a une corrélation négative entre les titres du complément sérique et ceux du facteur rhumatismal déterminé par $\frac{\sigma}{D}$ l'agglutination des globules sensibilisées de mouton ou $\vec{\nabla}$ par le procédé de précipitine. Un seul cas de maladie @ rhumatismale, où le titre du complément sérique était bas, est attribué à la présence de substances anticomplémentaires dans le sérum.

Dans le lupus érythémateux disséminé non-traité, $\overrightarrow{\vec{H}}$ le complément sérique est bas et on croit qu'il s'agisse $\vec{\omega}$ ici d'une vraie réduction du taux que l'on ne peut pas expliquer entièrement par la présence de substances anticomplémentaires. Cette théorie est supportée par? l'application d'un nouveau procédé de gel-diffusion $\vec{\infty}$ precipitin pour déterminer un composé d'un complément. $\omega$

On pense que l'élévation du complément sérique dans î la maladie rhumatismale est une réaction non-spécifique $\vec{\sigma}$ $\mathrm{du}$ processus inflammatoire, tandis que sa diminution 음 dans le lupus érythémateux s'explique par un mécanisme immunologique profond, lié in vivo aux réactions entre $\vec{c}$ l'antigène et l'anticorps fixant le complément.

Complemento sérico, factor reumatoide $\mathbf{y}$ otras proteinas séricas en la enfermedad reumatoide $y$ en el lupus eritematoso diseminado

SUMARIO

Se determinó el complemento sérico en 106 enfermo de los cuales 78 con enfermedad reumatoide, 18 c lupus eritematoso diseminado y 10 con varios d $\mathbb{s}^{5}$ turbios, como dermatomiositis, esclerodermia y poliarteritis nodosa.

En la enfermedad reumatoide, aunque en muchos casos las cifras del complemento sérico se ven aumen- $\mathbb{D}$ tadas, en otros éstas se encuentran dentro de los límites normales. El promedio para todos los casos de enfer-ō medad reumatoide está significativamente alzado. en 3 comparación con el promedio en 143 testigos. Hay correlación negativa entre las tasas del complemento sérico y las del factor reumático determinado por la aglutinación de globulos sensibilizados de oveja o por el procedimiento de precipitina. Un solo caso de enfer-o medad reumatoide, en el cual la tasa del complemento sérico fué baja, se atribuye a la presencia de substancias $\underline{3}$. anticomplementarias en el suero.

En el lupus eritematoso diseminado sin tratar, el complemento sérico está bajo; se cree que se trataría aquí de una reducción verdadera de la concentración, que no음 se puede explicar enteramente por la presencia de substancias anticomplementarias. Este concepto se veo apoyado por los resultados de un nuevo procedimiento de gel-diffusion precipitin para determinar un compuestoN de un complemento.

Se cree que el aumento del complemento sérico en la N enfermedad reumatoide constituye una reacción non-N específica del proceso inflamatorio, mientras que sue baja en el lupus eritematoso se explica por un mecanisma imunológico profundo, ligado in vivo a reacciones entreo al antígeno y el anticuerpo resultando en la fijación del complemento. 